\title{
Pengaruh Model Pembelajaran Predict-Observe-Explain (POE) Berbantuan Simulasi Virtual Terhadap Penguasaan Konsep Fisika Siswa SMA
}

\author{
Nurbaiti, Kosim*, Muhammad Taufik \\ Program Studi Pendidikan Fisika, Universitas Mataram \\ *Email: kosim_fisika@unram.ac.id
}

Received: 8 Desember 2019;

Accepted: 8 Mei 2020;

Published: 14 Juni 2020

DOI: http://dx.doi.org/10.29303/jpft.v6i1.1456

\begin{abstract}
This study aims to determine the effect of Predict-Observe-Explain (POE) learning models assisted by virtual simulations on the mastery of physics concepts in high school students. This type of research is a quasi-experimental with non-equivalent control group design. The population was all students of class X MIA MAN 2 Central Lombok, amount to 47 students with a sampling technique using saturated sample techniques, hence the sample used in this study was class X MIA-1 as an experimental group of 24 students and class X MIA- 2 as a control group of 23 students. Before being treated, both samples were given a preliminary test to determine their initial abilities. Based on homogeneity test results, both samples have the same initial ability. In the final test, obtained an average score of mastery of concepts from the experimental class of 66 with the highest score of 85 and an average score of the control class of 55 with the highest score of 75. The research hypothesis was tested with the t-polled variance test with a significance level of 5\%, and the results obtained t_count $=3.63$, while t_table $=$ 2.02. Based on these results, it means that $t_{-}$count is greater than $t_{-}$table, so $H_{o}$ is rejected. Thus, the conclusion is the Predict-Observe-Explain (POE) learning model assisted by virtual simulations has an influence on the mastery of physics concepts in high school students.
\end{abstract}

Keywords: Predict-Observe-Explain (POE), virtual simulations, mastery of concepts.

\section{PENDAHULUAN}

Fisika merupakan bagian dari sains yang memfokuskan kajiannya pada materi, energi, dan hubungan antara keduanya (Gunawan et al. 2015). Fokus kajian pada hal tersebut menyebabkan adanya konsep fisika yang bersifat nyata dan bersifat abstrak. Konsep fisika yang abstrak seringkali menyebabkan kesulitan bagi guru dan siswa dalam menjelaskan serta memahami konsep tersebut, sehingga dibutuhkan suatu model pembelajaran yang ideal dan media pembelajaran yang dapat dimanfaatkan oleh guru untuk mendukung tercapainya tujuan pembelajaran fisika.

Hasil observasi berupa interview yang telah dilakukan di MAN 2 Lombok Tengah pada tanggal 20 Oktober 2018, Peneliti menemukan bahwa dalam pembelajaran fisika guru kurang memvariasikan model pembelajaran dalam menjelaskan materi dan kurang mendorong siswa untuk aktif dalam pembelajaran, guru lebih banyak memberikan konsep berupa materi dan contoh yang cenderung dihafal tanpa dipahami oleh siswa, karena kurangnya variasi model pembelajaran dan pemanfaatan media pembelajaran serta pembelajaran yang bersifat satu arah atau berpusat pada guru membuat siswa merasa bosan, minat belajar siswa rendah, sehingga siswa menganggap pelajaran fisika terlalu sulit. Selain itu, kondisi laboratorium fisika sekolah kurang memadai, hal ini terlihat dari alat dan bahan laboratorium untuk melakukan eksperimen tidak lengkap dan banyak yang tidak layak pakai, sehingga guru tidak pernah melakukan kegiatan praktikum. Guru perlu melakukan perubahan dalam proses pembelajaran guna meningkatkan penguasaan konsep fisika siswa. Penguasaan konsep memegang 
peranan penting dalam pembelajaran fisika. Siswa dituntut untuk menguasai konsepkonsep fisika sehingga mampu untuk mengembangkan pengetahuan dan kemampuannya dalam memecahkan permasalahan fisika yang dihadapinya.

Berdasarkan permasalahan tersebut, maka diperlukan model pembelajaran yang mampu melibatkan siswa secara aktif, sehingga pembelajaran menjadi lebih bermakna. Pembelajaran fisika dengan menggunakan model pembelajaran yang lebih bervariasi serta proses pembelajaran yang berpusat pada siswa dapat menjadikan siswa berperan aktif dalam proses pembelajaran. Salah satu model pembelajaran yang dapat diterapkan adalah Prediction, Observation and Explaination (POE) yang pertama kali dikembangkan oleh White dan Gunstone pada tahun 1992.

Model pembelajaran POE adalah singkatan dari Prediction, Observation and Explaination. POE dikembangkan oleh White dan Gunstone pada tahun 1992. Pembelajaran dengan model ini menggunakan tiga langkah utama dari metode ilmiah, yaitu (1) Prediction atau membuat prediksi, membuat dugaan terhadap suatu peristiwa fisika; (2) Observation yaitu melakukan penelitian, pengamatan apa yang terjadi. Pertanyaan pokok dalam observasi adalah apakah prediksinya memang terjadi atau tidak; (3) Explaination yaitu memberikan penjelasan tentang kesesuaian antara dugaan dan yang sungguh terjadi (Suparno, 2013).

Menurut Warsono dan Hariyanto (2017) bahwa model POE berlandaskan pada teori pembelajaran kontruktivisme yang beranggapan bahwa melalui kegiatan prediksi, observasi dan penjelasan suatu hasil pengamatan, maka struktur kognitifnya akan terbentuk dengan baik. Jadi, dengan model pembelajaran POE ini siswa akan dapat membangun pengetahuannya melalui interaksi dengan guru maupun teman sebayanya. Model pembelajaran POE memiliki keunggulan, seperti digunakan untuk mengungkap gagasan awal siswa, membangkitkan diskusi, memberikan informasi kepada guru tentang pemikiran siswa dan memotivasi siswa agar berkeinginan untuk melakukan eksplorasi konsep serta membangkitkan keinginan untuk menyelidiki. Menurut Safitri et al. (2019) mengatakan model POE memberikan pengaruh yang signifikan terhadap aktivitas belajar dan penguasaan konsep siswa.

Selain penerapan model pembelajaran POE, penggunaan media pembelajaran juga berperan penting dalam proses pembelajaran. Salah satu alternatif media pembelajaran yang dapat digunakan adalah media simulasi berupa simulasi virtual. Simulasi virtual yang digunakan berupa simulasi yang sudah ada yakni program adobe flash player untuk submateri momentum dan impuls dan program Physics Education Technology (PhET) yang telah dipatenkan oleh Universitas Colorado untuk submateri hukum kekekalan momentum dan tumbukan.

Menurut (Wieman et al. 2010) Simulasi PhET dapat membantu untuk memperkenalkan topik baru, membangun konsep atau keterampilan, memperkuat ide, memberikan resensi akhir dan refleksi. Simulasi virtual bertujuan agar siswa memiliki kesempatan untuk belajar dalam menerapkan keterampilan dunia nyata agar memudahkan siswa dalam memahami konsep dan mengurangi persepsi yang ambigu dan abstrak. Penggunaan simulasi virtual juga dapat memberikan solusi terhadap fakta yang ditemui di lapangan terkait kondisi laboratorium fisika yang kurang memadai.

Perpaduan model pembelajaran POE dengan bantuan media simulasi memungkinkan proses pembelajaran 
menjadi lebih efektif. Siswa disajikan masalah-masalah fisika melalui simulasi virtual sehingga siswa akan terlibat di dalamnya, proses pembelajaran lebih menarik dan tujuan pembelajaran dapat tersampaikan dengan baik dan jelas. Selain itu, belum adanya penerapan model pembelajaran POE yang dipadukan dengan simulasi virtual. Peneliti tertarik melakukan penelitian di MAN 2 Lombok Tengah dengan menggunakan model pembelajaran POE berbantuan simulasi virtual. Peneliti berharap penggunaan model ini mampu meningkatkan penguasaan konsep siswa pada pembelajaran fisika.

\section{METODE PENELITIAN}

Jenis penelitian yang digunakan adalah Quasi Eksperimen dengan desain penelitian Non Equivalent Control Group. Penelitian ini melibatkan tiga variabel yaitu variabel bebas berupa model pembelajaran POE berbantuan simulasi virtual, variabel terikat berupa penguasaan konsep dan variabel kontrol berupa materi ajar pada impuls dan momentum, peneliti sebagai guru dan instrumen penilaian berupa pilihan ganda.

Populasi dalam penelitian ini adalah seluruh siswa kelas X MIA MAN 2 Lombok Tengah tahun pelajaran 2018/2019 yang berjumlah 47 siswa, yaitu kelas X MIA-1 yang berjumlah 24 siswa dan kelas X MIA2 yang berjumlah 23 siswa. Teknik pengambilan sampel yang digunakan adalah sampel jenuh. Sampel jenuh adalah teknik penentuan sampel bila semua anggota populasi digunakan sebagai sampel (Sugiyono, 2016).

Peneliti memilih sampel penelitian baik untuk kelas eksperimen maupun kelas kontrol karena populasi penelitian ini hanya ada dua kelas. Peneliti juga mempertimbangkan karakteristik kedua kelas yang hampir sama yang telah diketahui melalui observasi awal dengan tujuan agar lebih mudah untuk melakukan pengkondisian kelas. Pemilihan kedua kelas ini juga berdasarkan hasil interview dengan guru fisika di sekolah tersebut, bahwa hasil belajar fisika siswa kelas X MIA-1 maupun siswa kelas $\mathrm{X}$ MIA-2 tidak terdapat perbedaan yang signifikan. Hal ini berarti kemampuan siswa kedua kelas tersebut hampir sama. Selain itu, kedua kelas memiliki alokasi waktu belajar yang sama. Pemberian perlakuan berupa penerapan model pembelajaran POE berbantuan simulasi virtual pada kelas X MIA 1 sebagai kelas eksperimen dan pembelajaran konvensional berupa model pembelajaran langsung pada kelas X MIA 2 sebagai kelas kontrol.

Instrumen penelitian yang digunakan adalah tes pilihan ganda dengan lima alternatif jawaban. Setelah diuji validitas, realibilitas, tingkat kesukaran, dan daya beda soal diperoleh 20 soal yang tersebar pada setiap submateri. Indikator penguasaan konsep yang digunakan dalam tes ini terdiri dari enam indikator, yaitu $\mathrm{C} 1$ (mengingat), C2 (memahami), C3 (menerapkan), C4 (menganalisa), C5 (mengevaluasi), dan C6 (mencipta).

Uji hipotesis dalam penelitian ini menggunakan uji-t dengan taraf signifikan $5 \%$ dan derajat kebebasan $\left(n_{1}+n_{2}\right)-2$ dengan syarat telah terdistribusi normal dan homogen. Digunakan pula uji N-gain untuk mengetahui peningkatan penguasaan konsep fisika siswa per sub materi pada kelas eksperimen dan kelas kontrol

Penelitian ini dilakukan dengan memberikan perlakuan pada kelas eksperimen berupa model pembelajaran POE berbantuan simulasi virtual dan menerapkan pembelajaran konvensional pada kelas kontrol. Kedua kelas diberikan perlakuan selama tiga kali pertemuan dengan alokasi waktu setiap pertemuan 
selama 90 menit atau 2 jam pelajaran pada materi momentum dan impuls.

\section{HASIL DAN PEMBAHASAN}

Penelitian ini bertujuan untuk mengetahui pengaruh model pembelajaran POE berbantuan simulasi virtual terhadap penguasaan konsep fisika siswa SMA yang dilakukan pada siswa kelas X MIA MAN 2 Lombok Tengah. Penelitian dilakukan dengan memberikan perlakuan berupa penerapan model pembelajaran $\mathrm{POE}$ berbantuan simulasi virtual pada kelas $\mathrm{X}$ MIA 1 sebagai kelas eksperimen dan pembelajaran konvensional berupa model pembelajaran langsung pada kelas X MIA 2 sebagai kelas kontrol.

Pengambilan data penelitian dilakukan sebelum dan sesudah diberikan perlakuan pada kedua kelas yaitu pada hasil tes awal dan tes akhir siswa. Pengambilan data untuk data penguasaan konsep awal dan akhir siswa dilakukan dengan memberikan tes, yaitu tes awal dan tes akhir. Tes berupa tes obyektif dengan bentuk tes pilihan ganda sebanyak 20 soal dan sebelum mendapatkan 20 soal, Peneliti melakukan uji validitas soal pada kelas XI IPA-2 di SMAN 1 Kuripan dengan membuat 25 soal. Berdasarkan pertimbangan-pertimbangan uji analisis soal lainnya, seperti uji validitas, uji reliabilitas, indeks kesukaran dan daya beda, sehingga didapatkan 19 soal yang diterima, 5 soal dibuang atau ditolak dan 1 soal yang direvisi, yaitu dengan mengubah urutan opsi jawaban. Peneliti menyimpulkan untuk mengambil 20 soal untuk diberikan ke siswa pada saat melakukan tes awal dan tes akhir.

Kemampuan awal penguasaan konsep siswa baik kelas eksperimen maupun kelas kontrol berdasarkan hasil tes awal masih rendah. Nilai rata-rata tes awal penguasaan konsep masing-masing kelas, yaitu untuk kelas eksperimen 35 dan untuk kelas kontrol 32. Hal ini disebabkan karena siswa belum mendapat perlakuan, materi tentang momentum dan impuls belum pernah diajarkan dan pengetahuan yang dimiliki hanya berupa pengetahuan dasar yang diperoleh dalam kehidupan sehari-hari. Selain itu, kurangnya kemampuan awal siswa untuk menghubungkan pengetahuan yang lama dengan pengetahuan baru dan bagaimana mengkonstrusikan pengetahuan tersebut, sehingga solusi yang diterapkan oleh Peneliti adalah menerapkan model pembelajaran POE berbantuan simulasi virtual dalam proses pembelajaran. Berdasarkan hasil uji homogenitas tes awal yang telah dilakukan, diperoleh bahwa kedua sampel (kelas eksperimen dan kelas kontrol) homogen, yang berarti kedua kelas memiliki kemampuan awal yang sama, maka kedua kelas dapat diberikan perlakuan. Kelas eksperimen diberikan perlakuan model pembelajaran POE berbantuan simulasi virtual, sedangkan kelas kontrol diberikan perlakuan model pembelajaran konvensional di sekolah, yakni model pembelajaran langsung tanpa berbantuan simulasi virtual.

Penerapan model pembelajaran POE di kelas eksperimen memberikan hasil yang lebih baik terhadap penguasaan konsep siswa dibandingkan dengan kelas kontrol yang diterapkan model pembelajaran konvensional berupa model pembelajaran langsung, hal tersebut dapat dilihat dari hasil tes penguasaan konsep yang menunjukkan adanya peningkatan yang lebih tinggi pada tes akhir kelas eksperimen dibandingkan kelas kontrol. Hasil analisis tes akhir penguasaan konsep yang telah dilakukan didapatkan nilai rata-rata kelas eksperimen sebesar 66 dengan nilai tertinggi 85 dan nilai terendah 50, sedangkan nilai rata-rata kelas kontrol sebesar 55 dengan nilai tertinggi 75 dan nilai terendah 40. Hasil penelitian yang sudah dilakukan menggambarkan bahwa kemampuan akhir penguasaan konsep siswa 
berbeda dengan kemampuan awalnya. Kelas eksperimen maupun kelas kontrol mengalami peningkatan. Nilai rata-rata kelas eksperimen mengalami peningkatan sebesar 31 dan kelas kontrol meningkat sebesar 23. Peningkatan kelas eksperimen lebih baik daripada peningkatan pada kelas kontrol. Hal ini disebabkan karena pada kelas eksperimen menggunakan model pembelajaran POE berbantuan simulasi virtual.

Berdasarkan hasil tes akhir, kedua kelas sama-sama mengalami peningkatan Jika dibandingkan dengan nilai rata-rata pada tes awal. Sementara untuk mengetahui perbedaan peningkatan yang dialami oleh kedua kelas secara kuantitatif serta pengaruh dari model yang diberikan, maka perlu dilakukan uji hipotesis. Uji hipotesis yang digunakan dalam penelitian ini adalah uji-t polled varians karena sampel merupakan kelas yang homogen dan data yang dihasilkan terdistribusi normal.

Berdasarkan hasil perhitungan uji-t dilakukan untuk menguji hipotesis penelitian, yakni menggunakan uji-t polled varians berdasarkan persamaan 3.8. Hasil perhitungan diperoleh $t_{\text {hitung }}=3.63$ dan $t_{\text {tabel }}=2.02$ dengan tingkat signifikansi $5 \%$,karena $t_{\text {hitung }}>t_{\text {tabel }}$ yaitu $3.63>$ 2.02, maka Ho ditolak. Hal ini menunjukkan bahwa kelas eksperimen yang diberikan perlakuan berupa penerapan model pembelajaran POE berbantuan simulasi virtual berpengaruh terhadap penguasaan konsep fisika siswa.

Sebagai tindak lanjut dari analisis data, dilakukan uji N-gain untuk mengetahui peningkatan nilai per sub materi pada kedua kelas. Uji N-Gain berfungsi untuk mengetahui perbedaan signifikan hasil perolehan nilai kelas kontrol dengan kelas eksperimen. Selain itu, Gunawan et al. (2015) mengungkapkan bahwa uji N-Gain dilakukan dalam rangka antisipasi kesalahan penafsiran perolehan skor gain setiap siswa. Peningkatan penguasaan konsep fisika siswa setiap submateri dapat dilihat pada Gambar 1 berikut.

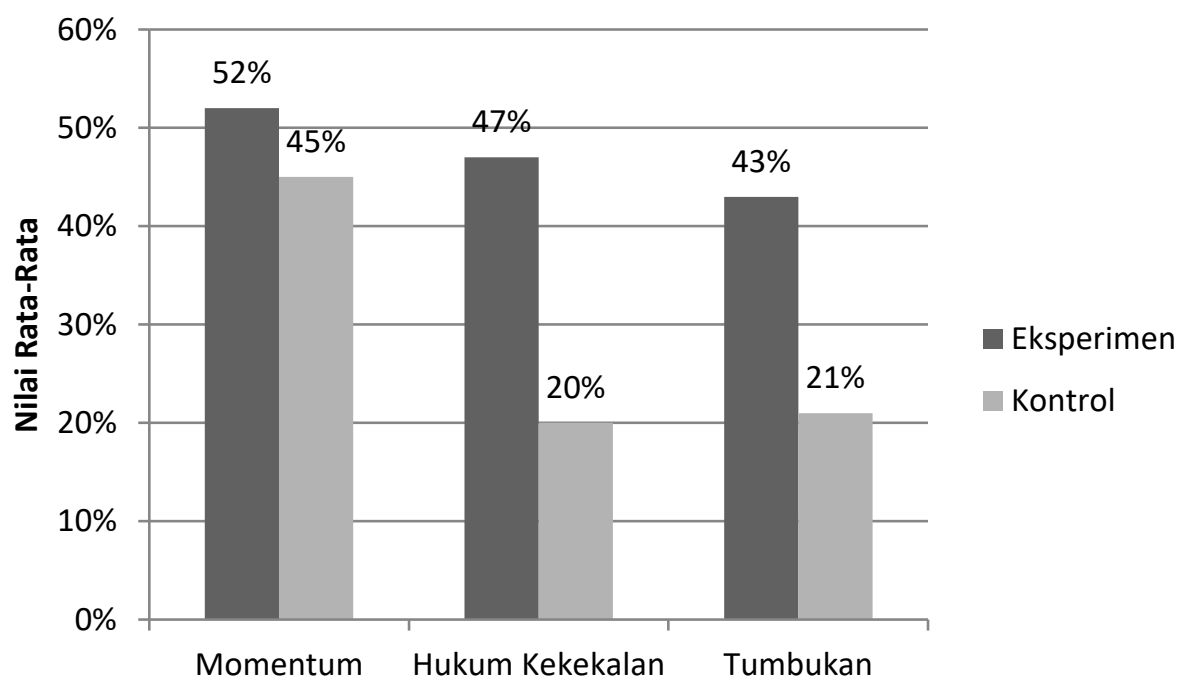

Gambar 1. Rata-rata nilai siswa pada tiap sub materi

Berdasarkan hasil analisis uji N-gain setiap submateri pada gambar 1, menunjukkan bahwa kelas eksperimen mengalami peningkatan yang lebih tinggi daripada kelas kontrol diantaranya, yaitu persentase peningkatan pada submateri momentum dan impuls sebesar $52 \%$ pada kelas eksperimen dan $45 \%$ pada kelas kontrol. Hal ini disebabkan karena dalam proses pembelajaran pada kelas eksperimen berjalan baik untuk submateri tersebut, lebih cepat memahami dan menguasai konsep 
serta mampu memecahkan masalah pada soal dibandingkan dengan kelas kontrol. Perbedaan peningkatan yang signifikan pada kedua kelas terdapat pada submateri hukum kekekalan momentum dan tumbukan. Persentase submateri hukum kekekalan pada kelas eksperimen sebesar $47 \%$ dan pada kelas kontrol sebesar 20\%, sedangkan pada submateri tumbukan, persentase pada kelas eksperimen sebesar $43 \%$ dan pada kelas kontrol sebesar $21 \%$. Perbedaan perolehan ini, disebabkan karena kemampuan pada kelas eksperimen yang lebih baik daripada kelas kontrol untuk kedua submateri terlihat dari kemampuan penguasaan konsep, penyelesaian beberapa soal yang termasuk dalam kategori sukar pada ranah kognitif tingkat tinggi, yaitu C4 (menganalisis), C5 (mengevaluasi) dan C6 (mencipta), yang menuntut siswa untuk bisa memformulasikan persamaan matematis, menggunakan rumus pada soal hitungan dan terdapat soal berbentuk teori yang membutuhkan kemampuan berpikir lebih tinggi untuk menyelesaikan masalah serta siswa pada kelas eksperimen lebih aktif dan antusias saat mengikuti proses pembelajaran. Hal ini menunjukkan bahwa persentase nilai pada kelas eksperimen lebih tinggi dari kelas kontrol, sehingga penerapan model pembelajaran POE berbantuan simulasi virtual berpengaruh pada kelas eksperimen untuk materi momentum dan impuls. Namun, pengaruh yang lebih tinggi terkait penerapan model pembelajaran POE berbantuan simulasi virtual terhadap penguasaan konsep fisika pada kelas eksperimen terlihat pada submateri hukum kekekalan momentum dan tumbukan. Oleh karena itu, penerapan model pembelajaran POE berbantuan simulasi virtual berpengaruh pada kelas eksperimen.

Hasil ini diperkuat beberapa penelitian sebelumnya, seperti penelitian yang dilakukan (Samudera et al. 2017) dan
(Safitri et al. 2019) tentang model pembelajaran POE memberikan pengaruh yang signifikan terhadap hasil belajar fisika siswa, aktivitas belajar dan penguasaan konsep siswa. Penelitian terkait dengan penggunaan simulasi virtual dalam pembelajaran, antara lain (Arianti et al. 2016) menyatakan bahwa terdapat pengaruh penerapan model direct instruction berbantuan simulasi virtual terhadap penguasaan konsep dan pemecahan masalah fisika siswa. Menurut (Jauhari et al. 2016) menyatakan bahwa kelas eksperimen yang diberikan perlakuan model pembelajaran berbasis masalah berbantuan media PhET, lebih aktif dan antusias saat mengikuti proses pembelajaran serta memiliki kemampuan akhir kognitif yang lebih tinggi dilihat dari peningkatan hasil belajarnya daripada kelas kontrol yang diberikan perlakuan model pembelajaran konvensional. Selain itu, menurut Lidiana $e t$ al. (2018) menyatakan bahwa hasil belajar menggunakan model pembelajaran inquiri dengan menggunakan media simulasi PhET lebih tinggi dari hasil belajar siswa yang menggunakan model pembelajaran konvensional.

\section{PENUTUP}

Berdasarkan uji hipotesis, dapat disimpulkan bahwa model pembelajaran POE berbantuan simulasi virtual berpengaruh terhadap penguasaan konsep fisika siswa kelas X MIA MAN 2 Lombok Tengah. Hasil uji $\mathrm{N}$-gain diperoleh peningkatan penguasaan konsep fisika siswa yang diajar menggunakan model pembelajaran POE berbantuan simulasi virtual pada kelas eksperimen lebih baik daripada kelas kontrol yang diajar dengan menggunakan model pembelajaran konvensional untuk materi momentum dan impuls. 
Model pembelajaran POE berbantuan simulasi virtual ini dapat diterapkan untuk meningkatkan penguasaan konsep fisika siswa dengan memperhatikan beberapa hal, yaitu, simulasi virtual harus sesuai dengan indikator pembelajaran dan sudah dipahami cara penggunaanya. LKPD juga harus dibuat lebih sederhana, jelas dan menarik serta diberikan kepada setiap siswa agar lebih mudah dalam memahaminya. Serta penginstalan aplikasi simulasi virtual disertai dengan aplikasi penunjang seperti Java, Firefox dan Adobe Flash Player.

\section{REFERENSI}

Arianti, B., Sahidu, H., Harjono, A., \& Gunawan, G. (2016). Pengaruh Model Direct Instruction Berbantuan Simulasi Virtual Terhadap Penguasaan Konsep Siswa. Jurnal Pendidikan Fisika dan Teknologi, 2(4), 159-163.

Darmawan, I. P. A., \& Sujoko, E. (2013). Revisi Taksonomi Pembelajaran Benyamin S. Bloom. Satya Widya, 29(1), 30-39.

Gunawan. (2015). Model Pembelajaran Sains Berbasis ICT. Mataram: FKIP UNRAM.

Gunawan, G., Harjono, A., \& Sutrio, S. (2015). Multimedia Interaktif dalam Pembelajaran Konsep Listrik bagi Calon Guru. Jurnal Pendidikan Fisika dan Teknologi, 1(1), 9-14.

Hermansyah., Gunawan., \& Herayanti, L. 2015. Pengaruh Penggunaan Laboratorium Virtual Terhadap Penguasaan Konsep dan Kemampuan Berpikir Kreatif Siswa pada Materi Getaran Dan Gelombang. Jurnal Pendidikan Fisika dan Teknologi. Vol. 1, No. 2: 3.

Jauhari, T., Hikmawati, H., \& Wahyudi, W. (2016). Pengaruh Model Pembelajaran Berbasis Masalah Berbantuan Media Phet Terhadap
Hasil Belajar Fisika Siswa Kelas X SMAN 1 Gunungsari Tahun Pelajaran 2015/2016. Jurnal Pendidikan Fisika dan Teknologi, 2(1), 7-12.

Lidiana, H., Gunawan., \& Taufik, M. (2018). Pengaruh Model Discovery Learning Berbantuan Media PhET Terhadap Hasil Belajar Fisika Peserta Didik Kelas XI SMAN 1 Kediri Tahun Ajaran 2017/2018. Jurnal Pendidikan Fisika dan Teknologi, 4(1), 33-39.

Samudera, V. M., Rokhmat, J., \& Wahyudi. (2017). Pengaruh Model Pembelajaran Predict-ObserveExplain Terhadap Hasil Belajar Fisika Siswa Ditinjau Dari Sikap Ilmiah. Jurnal Pendidikan Fisika dan Teknologi, 3(1), 101-108.

Sugiyono. (2016). Metode Penelitian Pendidikan: Pendekatan Kuantitatif, Kualitatif, dan $R \& D$. Bandung: Alfabeta.

Suparno, P. SJ. (2013). Metodologi Pembelajaran Fisika Konstruktivistik \& Menyenangkan. Gejayan Yogyakarta: USD.

Warsono \& Hariyanto. (2017). Pembelajaran Aktif. Bandung: PT. Remaja Rosdakarya.

Wieman, C. E., Adams, W. K., Loeblein, P., \& Perkins, K. K. (2010). Teaching Physics Using PhET Simulations. The Physics Teacher, 48(4), 225-227. 